\title{
The experience and teaching innovations in education at the Universities of Siberia
}

\section{Pokasov}

V. V. Pokasov, "The experience and teaching innovations in education at the Universities of Siberia," Proc. SPIE 9663, Eighth International Topical Meeting on Education and Training in Optics and Photonics, 966314 (6 October 2003); doi: $10.1117 / 12.2207484$

SPIE Event: Eighth International Topical Meeting on Education and Training in Optics and Photonics, 2003, Tucson, Arizona, United States 


\title{
The experience and teaching innovations in education at the Universities of Siberia
}

\author{
V. V. Pokasov \\ Physical-Technical Department, Novosibirsk State Technical University, pr. Marksa 20, Novosibirsk 630092Russia \\ vpokasov@laser.nsc.ru
}

\begin{abstract}
The experience of joint work of Tomsk and Novosibirsk academic institutes and universities on the education of students and professional training of young specialists for scientific and industrial enterprises is generalized.

(C)2003 Optical Society of America

OCIS codes: (000.0000) General; (000.2060) Education
\end{abstract}

\section{Introduction}

There is a proverb: "every cook praises his own broth". And in the well-known years of the Soviet Experiment, we resembled such a cook. This happened not because of our snobbery, but due to the absence of objective information about the situation in other countries. Now, we have a new "informational" situation, and there appeared an opportunity of contacts. We wish to get acquainted with the experience and innovations of our colleagues from other countries. We would also like to inform our colleagues about our own experience. Of course, one cannot do without the discussion of problems and shortcomings. This is especially important in the modern conditions of developing integration of the world science and high professional mobility of specialists.

I shall not go deep into general conceptual questions of the educational system in Russia. I will consider mainly those questions that concern directly the training of students, the professional training of specialists in the fields of optics, photonics, laser engineering, and technologies.

At the present time, we experience a change in the public formation. The political, economic, and social situations have changed abruptly. In all spheres of management, ideas of reformation are actively put forward. Unfortunately, this process is not always for the better. Our education system did not avoid this. Therefore, they say, it is important not to "throw the baby out with the bath water". It is necessary to choose and leave all the best that was accumulated in the previous period, and to develop new innovation solutions for the new situation. This is especially important, because sometimes it happens so that the new is simply a long-forgotten old.

\section{2. "Phystech-System" in Siberia}

For simplicity, let "before" denote the previous pre-reform period and "now" the present-day period. I know what it feels like in such periods, and I experienced this both in Tomsk and Novosibirsk. Both cities are rather important in Russia as large centers of education and science. Tomsk, with a history of more than four hundred years, has the first Siberian university. In more than a hundred years, Tomsk University became one of the leading universities of Russia, the basic highly professional educational establishment among other Siberian universities. Therefore, it is a place where specialists for the creation of new equipment and technologies for scientific and industrial enterprises are prepared. In 1969, the development of a Tomsk Scientific Center of the Siberian Branch of Russian Academy of Sciences begins in it.

Novosibirsk is a young city. Nowadays, however, it is one of the largest Russian centers of science, where there is the Siberian Branch of Russian Academy of Sciences, some large industrial enterprises, and 16 higher educational institutions, including two universities. They include Novosibirsk State University (NSU), a classical university of the Siberian Branch of Russian Academy of Sciences and Novosibirsk State Technical University (NSTU).

The so-called "Phystech-System" was an effective innovation solution in the field of education. It was realized for the first time in early 50ies, at the creation of a higher educational establishment of a new type, namely, the Moscow Physics-Technical Institute. Its basic principles are as follows:

- Search for potentially talented schoolchildren and their selection owing to the available system of internal and extra-mural physical and mathematical Olympiads and physical-mathematical summer schools.

- Active (both economic and ideological) support of the state to motivate young people for education and professional work in the scientific-technical sphere.

- Involvement of outstanding scientists and engineers for delivering lectures. 
- Professional training of students through their direct participation in the work of leading scientific and technical teams in academic institutions and industrial enterprises. Their active work in creative laboratories headed by world-famous scientists and engineers.

- Atmosphere of creative competitiveness owing to the participation in scientific seminars, discussions, and conferences.

- Allocation of money for new scientific equipment for teaching laboratories.

- Guarantee of prestigious, well-paid (for our country's conditions) jobs.

First, of course, this was made, as an exception, only for Moscow. Some elements of this system were used in other places, in particular, in Leningrad (now called St.-Petersburg). In large universities of Siberia, such as Tomsk and Novosibirsk, considered below, this system was developed further.

Alongside with a free inflow of students entering the university after passing entrance examinations, the universities search for and select talented young people - school graduates. For this purpose, there exists a system of Olympiads and specialized physical and mathematical schools (see Fig.1).

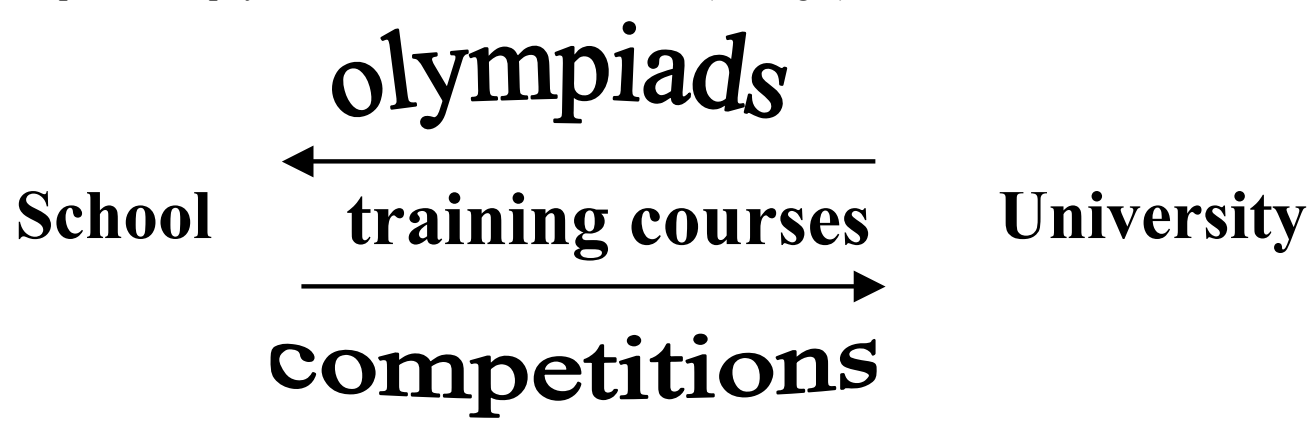

Fig. 1. Scheme for student selection.

Certain scientific - educational complexes were formed. Their structure is presented in Fig. 2.

TOMSK city

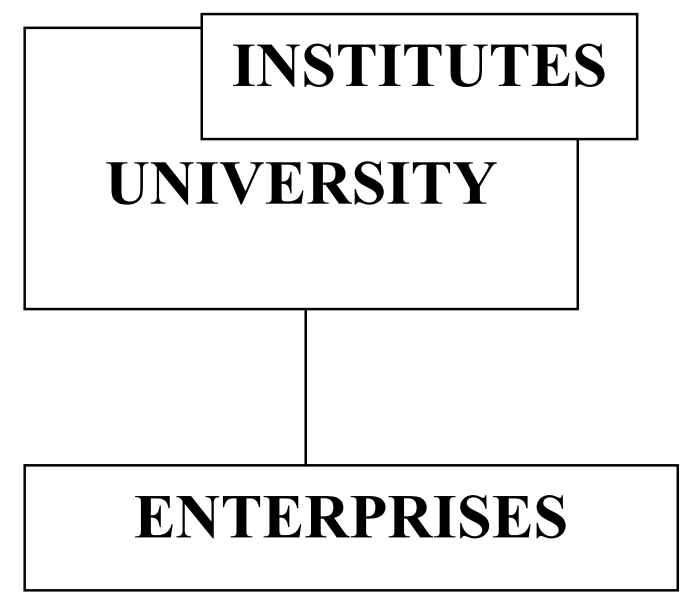

NOVOSIBIRSK city

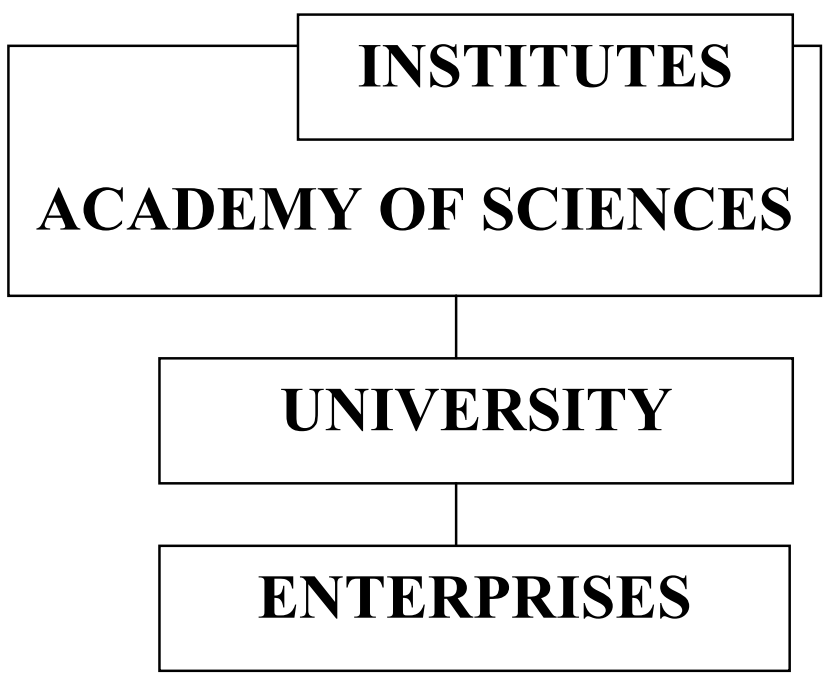

Fig. 1. Structure of university relations of Tomsk and Novosibirsk

The Tomsk State University, which is third in Russia now, first developed in accordance with the same principles and, maybe in some respects, anticipated the ideas of the Moscow "Phystech". Large scientific research institutes were created on the basis of the Tomsk University, who former graduates, became researchers of these institutes. The first of them was the Siberian Physics-technical Institute, which played an important role in the 
development and advancement of new equipment and technologies created in the 20th century. Its scientific laboratories had up-to-date equipment purchased for research orders. This contributed to a rapid raise of the level of training skills of the university professors and teachers, which were simultaneously institute workers. Scientific laboratories were the perfect bases for professional training of students. Later, several more scientific institutes were opened at the university, which also formed a basis for the educational process.

The university also played an important role in the development of other large higher educational establishments in Tomsk, such the as Polytechnical Institute (University), the Academy (University) of Control Systems and Radioelectronics, and some large industrial enterprises. In the 70es, the Tomsk Scientific Center of the Siberian Branch of Academy of Sciences was created. All this contributed to the organization of an effective training-scientific educational process [1].

Another interesting and important peculiarity of Tomsk is a unique atmosphere of the Students' Quarter. It facilitated a specific openness of scientific teams and personal relations between scientists and students. In 1961, a Chair of Optical Electronic Devices and Laser Physics was open. I was happened to be among its first graduates. Our young specialists worked at the first institute of the Academy of Sciences in Tomsk, the Institute of Atmospheric Optics, after its opening in 1969. The main directions of research of the Institute were investigation of the propagation of laser radiation in the atmosphere, laser spectroscopy, and problems of remote laser sounding of the atmosphere. The absence of dropout because of academic failure was a feature typical for those years.

The Novosibirsk Classical University was created directly in the structure of the Siberian Branch of Academy of Sciences, which was the initial place of work of many graduates of the Tomsk University and Moscow PhysTech. Therefore, the same concept of training as a unified educational-scientific process was used in the educational system of Novosibirsk higher educational establishments. Undergraduates, beginning with their third year of learning, become probationers - researchers at laboratories of academic institutes and get wages for their job. They participate in research projects, scientific seminars, and conferences.

The years of social and political restructuring ("perestroika") in Russia since 1985, have changed essentially the social conditions and priorities. Industrial depression, a low living standard, low wages, and a lot of new temptations of carefree life changed essentially the motivation of young people associated with the professional orientation to the sphere of science and engineering. Many highly qualified professors left the educational system. There was no more money for new equipment and devices for university teaching laboratories. Only unique scientific setups in academic institutes were kept at the up-to-date level. There still remained, however, the traditions of selfless work of scientists with students. As before, institutes provide its unique equipment for its joint use by teachers and students.

The scientific community always expresses its anxiety about this situation and, at last, it succeeded in getting a governmental decision on a long-term state program of financial support of a new educational concept based on the integration between the educational process and scientific research and development. The program called "Integration", although it gets small financial support, allows us to maintain a unique microclimate of a unified training-scientific "university - academy" medium. Institute of Laser Physics and Institute of Nuclear Physics, SB RAS, are basic institutes for the Physical-Technical Faculty of Novosibirsk Technical University (NSTU) and for the NSU Physical Faculty. Now, most leading specialists of these institutes are graduates of these faculties.

For instance, the following fact shows that the idea of "Integration" is useful. Since the situation with professions and social priorities has changed, there are many poorly prepared school graduates with poor motivation for study in physical and technical specialties. Regrettably, their only aim is to prolong the period of carefree life or avoid going to the army, since army service in Russia is not prestigious.

We do not reduce the requirements to the results of studies, and therefore many students (up to $40 \%$ ) have to leave the university after the first year of studies because of their poor results. Others, after visits to academic institutes, meetings with leading scientists, participation in scientific research, and first successes, change their motivation abruptly. In fact, each student has an individual scientific supervisor. The creative atmosphere of scientific laboratories "captivates" these students, and they are willingly dive into it. Although there are less than 3\% of people studying at the Physical-Technical Faculty of the NSTU, they always constitute a stable $30 \%$ proportion of prize-winners from the total number of all participants of Scientific Students' Conferences [2].

The reorganization caused one more distressing factor. Some young people became less responsive to pedagogical measures, personal relations became more complicated, and the attitude to the university property, devices, and equipment was no longer careful. Unfortunately, the ideas of freedom are often understood as permissiveness. I do not know whether we are right or not by assuming that the pedagogical component should also remain an immutable factor in relations with students during their university study. At the age of 18 , there are a lot of ambitions, but the personality is not yet formed. Young people yield to the temptation of street freedom, sometimes with harmful consequences. 
The inevitable need to adapt to the new economic situation and market relations resulted in one more contradictory situation in the field of education: the professors and teachers, as well as the university management naturally wish to maintain their professional level in science and the university prestige. For this, teaching and research laboratories need expensive modern equipment. To prepare a good specialist, provide a young man with a good social guide, highly qualified teachers and a certain infrastructure (library, gym, special recreation services, etc.) are required.

Only large universities can have a high-level infrastructure, highly qualified teachers, devices and equipment necessary for the educational process, and all other indispensable things. Nevertheless, the Ministry of Education, which does not have enough money, put forward and actively supports the idea of financing from the budget of the region, in which the university is located. Then some regional administration heads (they have no money either, and this can be understood) declared that they do not need large universities at their territory. This position is, of course, short-sighted, but we hope that these views will not prevail.

In this problem, however, there is certainly also a progressive element. Universities should make better use of their intellectual resource for innovation decisions to solve social-economic problems of regions, fundamental innovation positive changes in the technologies and social life of the society as a whole. Now, at last, large city enterprises have again begun to form special orders for young specialists in the production sphere. This inspires of optimism.

We have opened the first Student Branch of SPIE (Novosibirsk SPIE Student Chapter) in Russia, for which I would like to thank the SPIE management. This has opened up new interesting opportunities for students, and they can get access to scientific magazines and new information. In summary, I would like to note that we have both "troubles" and "victories", which are outlined in Table 1.

Table 1.

\begin{tabular}{|c|c|}
\hline BEFORE (a characteristic feature) & NOW (for the time being!) \\
\hline \multicolumn{2}{|c|}{ Social-economic situation: } \\
\hline - Free education at all levels & - Mixed education system (free and paid) \\
\hline $\begin{array}{l}\text { - High motivation to learning new engineering and } \\
\text { technology specialties (basis: high social } \\
\text { prestigiousness of professions) }\end{array}$ & $\begin{array}{l}\text { - Decreased motivation to learning engineering } \\
\text { and technology specialties (basis: low prestige of } \\
\text { professions) }\end{array}$ \\
\hline - Social safety of students' life; optimism. & - Difficult social conditions of students' life \\
\hline $\begin{array}{l}\text { - Absence of aggression in personal relations, } \\
\text { benevolence. }\end{array}$ & - Devaluation of human values, problems in \\
\hline $\begin{array}{l}\text { - Susceptibility to pedagogical measures, } \\
\text { consciousness }\end{array}$ & personal relations \\
\hline \multicolumn{2}{|c|}{ - Guaranteed employment (state orders) } \\
\hline \multicolumn{2}{|c|}{ Main educational technologies: } \\
\hline $\begin{array}{l}\text { - Auditor lessons (lectures, laboratory works, } \\
\text { practical lessons, seminars) }\end{array}$ & $\begin{array}{l}\text { - Auditor lessons (lectures, laboratory works, } \\
\text { practical lessons, seminars) }\end{array}$ \\
\hline $\begin{array}{l}\text { - Visits of enterprises, industrial and pre-diploma } \\
\text { practice }\end{array}$ & $\begin{array}{l}\text { - Computer technologies, possibility of remote } \\
\text { education (under development) }\end{array}$ \\
\hline & $\begin{array}{l}\text { - Integration of the educational process and works } \\
\text { in professional scientific and technical teams } \\
\text { (beginning with the second part of learning) }\end{array}$ \\
\hline \multicolumn{2}{|c|}{ Main shortcomings: } \\
\hline - Non-openness to the outside world & $\begin{array}{l}\text { - Insufficient number of the new textbooks and } \\
\text { monographs }\end{array}$ \\
\hline
\end{tabular}

\section{References}

1. V.V.Pokasov, V.P.Tarasenko, "Experience of Science-Education Integration," Vestnik Akademii Nauk, 5, 45-50, (1990)

2. Quality of Education, NSTU Bulletin, 2001 